\title{
MSW Management in Universities: Sharing Best Practices
}

\author{
Elena Cristina Rada ${ }^{1}\left(\mathbb{D}\right.$, Elena Romenovna Magaril ${ }^{2}{ }^{(}$, Marco Schiavon ${ }^{3, * \mathbb{C}}$, \\ Anzhelika Karaeva ${ }^{2}$, Maxim Chashchin ${ }^{2}$ and Vincenzo Torretta ${ }^{1, *(\mathbb{C})}$ \\ 1 Department of Theoretical and Applied Sciences, Insubria University of Varese, Via G.B. Vico 46, \\ 21100 Varese, Italy; elena.rada@uninsubria.it \\ 2 Department of Environmental Economics, Ural Federal University, Mira Str. 19, 620002 Ekaterinburg, Russia; \\ magaril67@mail.ru (E.R.M.); anzhelika.karaeva@gmail.com (A.K.); f123503@yandex.ru (M.C.) \\ 3 Department of Civil, Environmental and Mechanical Engineering, University of Trento, via Mesiano 77, \\ 38123 Trento, Italy \\ * Correspondence: marco.schiavon@unitn.it (M.S.); Vincenzo.torretta@uninsubria.it (V.T.); \\ Tel.: +39-0332-218-782 (V.T.)
}

Received: 16 May 2020; Accepted: 19 June 2020; Published: 22 June 2020

\begin{abstract}
The optimization of municipal solid waste management requires the re-organization of niche sectors too. The sector of the university is not fully explored from the scientific point of view. The creation of networks among universities in order to face this issue allows an exchange of expertise also at an international level as demonstrated in this article, by three case studies: two Italian (University of Trento and University of Insubria) and one Russian (Ural Federal University) universities. The study highlights the pros and cons of each university in terms of waste management. Specifically, setting up communication campaigns, standard procedures, monitoring actions, pricing strategies that incentivize selective collection, and improving the collaboration within the university community are identified as crucial initiatives. The margins of improvement of the three universities analyzed are favored by the composition of the generated waste. The implementation of good practices can give economic advantages to the universities, besides improving their level of sustainability.
\end{abstract}

Keywords: MSW; university; circular economy; selective collection; best practice; COVID-19

\section{Introduction}

Municipal solid waste (MSW) management was, and still is, one of the most studied topics. Waste production and characterization in large groups of young people attending universities, campuses, and schools are slowly beginning to interest the scientific community with in the last decade. The can be seen from recent publications included in the Scopus ${ }^{\circledR}$ database. To this concern, the interest has been focused on: the viability of decentralized biogas production from the food waste generated in a university compound [1], the potential valorization of food waste generated in primary and secondary schools through composting [2], the relevance of paper and cardboard in the waste generated at university level [3], the importance of involving university cafeterias and canteens in the source separation of food waste [4], the strategic role that sustainable waste management projects can have when involving the university community [5], the fact that instilling the right behavior in school children is also beneficial to the environmental behavior of their families [6], the high recyclability of waste generated in universities thanks to the presence of plastic and paper [7], and the seasonal variability of waste generated in university campuses [8]. Some scientists tried also to find a connection between education, knowledge, communication, and action for better MSW practices. The results demonstrated that: environmental education on source separation of waste in high schools must be 
performed while adopting scientific methods in case of small communities [9], school is the starting point to get a change of mindset, as speaking with students (all potential communicators) means communicating indirectly with all the other targets [10], the teaching of pro-environmental attitudes must be encouraged through a simultaneous information campaign in homogeneous territories [11], and communication campaigns must be based on a knowledge of the composition of MSW deeper than the past [12].

In Italy, in 2015, the RUS ${ }^{\circledR}$ —Network of Universities for Sustainable Development, was formed. The Network was made in order to offer the possibility to find, propose and share solutions for environmental sustainability and social responsibility among the Italian Universities, through the 17 Sustainable Development Goals (SDGs) [13]. Waste management is included in the SDG n. 12 ("Responsible consumption and production") and it represents a big responsibility for the Universities not only from the economic point of view but also from the environmental one. For this reason, a RUS $^{\circledR}$ Waste Working (WW) group was established and works considering the Circular Economy Packages regarding waste management.

In $2018,82 \%$ of the Italian universities belonged to RUS ${ }^{\circledR}$. The network developed an initial census on waste management in the $74 \%$ of universities who have joined the RUS ${ }^{\circledR}$ WW group [14]. The results showed that a quarter of them must implement waste management practices in a sustainable way in order to comply with the RUS ${ }^{\circledR}$ goals $[14,15]$.

The present paper aims at enlarging the database of universities and waste management practices by reporting the modalities through which MSW management is carried out in three universities. Two of them are located in Italy and comply with EU legislation and circular economy principles [16,17]. The third university is located in Russia, on the border between Europe and Asia, and is in the initial stage of MSW optimization [18-20].

\section{Materials and Methods}

In the present paper, three case studies are reported. The first case refers to a university that can be considered as a model for all the universities regarding waste management. The second case refers to a university that is in the developmental and implementation stage. The third case presents a university out of Italy, namely in Russian Federation (which is currently implementing a wide-scale municipal solid waste reform), that intends to propose itself as a starting model for all Russian universities.

The first case study is located in the northern part of Italy, in the Trentino Region. The region has developed an efficient selective collection (SC) system, aiming at an 85\% SC rate and a generation of only $45 \mathrm{~kg}$ of Residual Municipal Solid Waste (RMSW) per inhabitant. Present data are close to these targets. In this Region, the first MSW management plan was issued in 1993 and the fifth one is currently under preparation [21-23].

The University of Trento (UniTrento) is a medium-sized university located in the Trentino Region. UniTrento accounts for more than 18,000 people, including about 16,000 students. The university is composed of a high number of buildings and is divided into three main campuses:

- one uphill campus located in the town of Trento (about 117,000 inhabitants) with six departments,

- one downtown campus also located in Trento, with three departments, one faculty, and one research center),

- one campus in the town of Rovereto (about 39,000 inhabitants), including one department and one research center.

One more research center is hosted by the agricultural institute of San Michele all'Adige, about 14 $\mathrm{km}$ north from Trento. Figure 1 reports all the university buildings. 


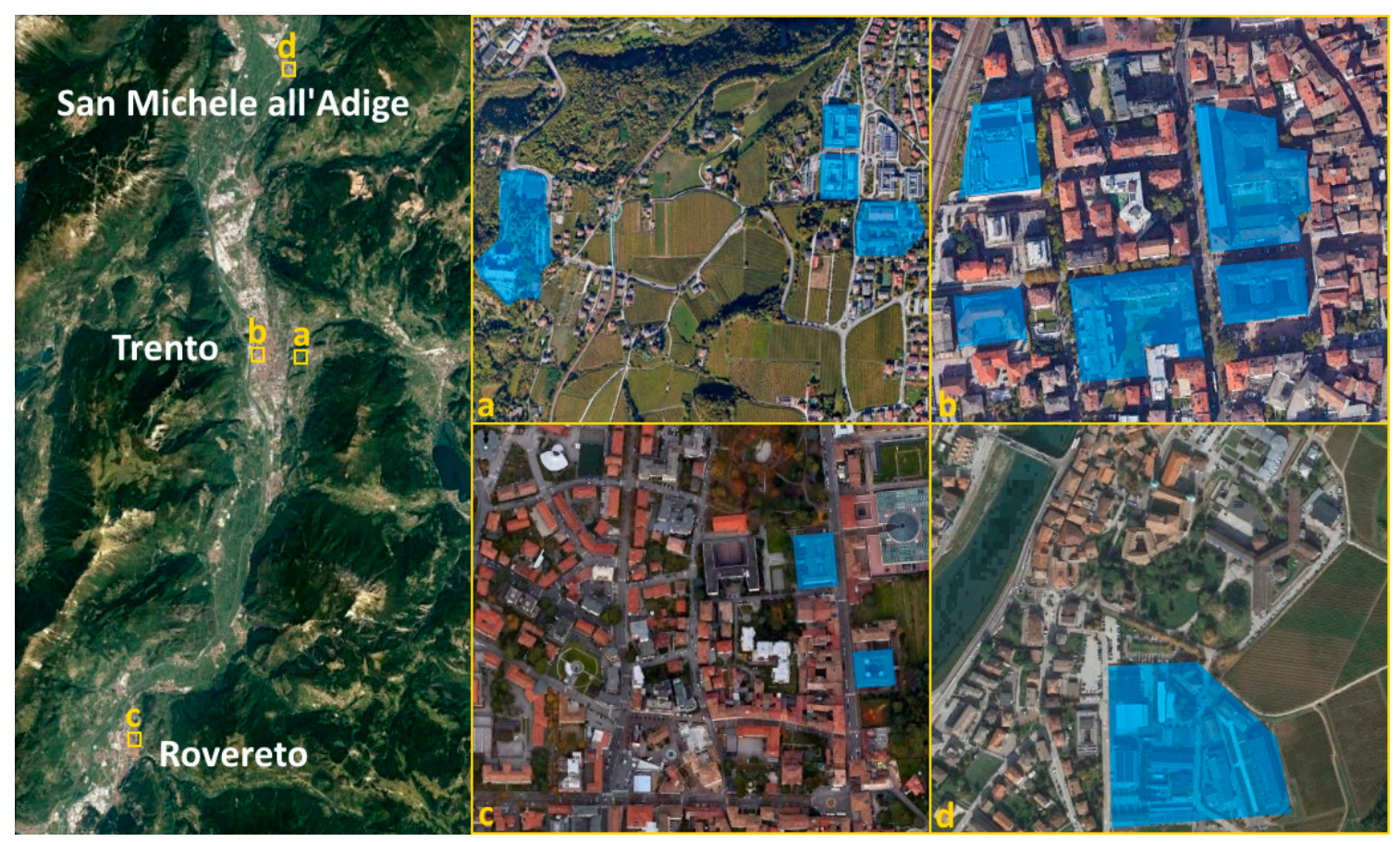

Figure 1. Locations of the University of Trento (UniTrento) campuses and research centers: (a) uphill campus, (b) downtown campus in Trento, (c) Rovereto campus and (d) research center hosted by the agricultural institute of San Michele all'Adige.

One of the main advantages of the waste collection system of UniTrento and, in general, of Trentino is the tariff system in use. Differently from other contexts, waste management is based on a "punctual tariff" system, which accounts for the effective volume of RMSW generated by the users. The users, thus, pay a fixed tax and a variable cost that depends on the amount of RMSW produced [24,25]. Such a system obliges the users to become responsible for their habits when purchasing products and when separating the waste.

The waste management system of UniTrento has been developed hand in hand with the regional system, due to the close relationship between the province of Trento and the university. Nowadays, SC is well-implemented in every building of UniTrento and is designed to collect paper and cardboard, light packaging (i.e., plastic and metal packaging), and the residual fraction of MSW (RMSW). In addition, in the nearby university canteens and bars, the SC is active also for the collection of glass and food waste. Food waste collection is also available near vending machines. All the waste fractions are collected by the local waste management company, which transfers the recyclable fractions to dedicated facilities where the materials enter the recycling circuit. The RMSW is sent to MSW landfills. UniTrento pays a fee for the management of RMSW, which is based on the surface of buildings (fixed tax) and a variable cost of $0.09 €$ per liter of excess RMSW produced.

The second case study is located in Lombardy (Italy). In 2018 the regional per capita production of urban waste was $478.7 \mathrm{~kg} \mathrm{ab}^{-1} \mathrm{y}^{-1}$. Waste SC amounted to 3,409,356 $\mathrm{t}$ in 2018, with an increase of $+4.5 \%$ compared to the previous year. A final overall indication that can constitute a starting point of evaluation is the per capita cost of managing urban waste at the regional level, which is equal to 126 euros. The value is lower than both the national average, equal to approximately 174 euros and that of the northern regions of Italy, equal to approximately 154 euros, demonstrating the overall good management of the integrated waste system, even after the substantial abandonment of the controlled landfill practice.

The Insubria University (Uninsubria) is a young medium-sized university born in 1998 and has three main locations: Varese, Como, and Busto Arsizio. Uninsubria has about 15,400 people, including 12,000 students. The university has about 40 buildings and two main campuses. The SC is 
not totally implemented. The starting point for better MSW management in Uninsubria begins with its participation in the RUS ${ }^{\circledR}$ WW group [26]. The first step was to develop and implement progressively an MSW management plan for all the university campuses, that includes several steps:

- analysis of current waste collection methods, including product analysis,

- cost analysis,

- assessment questionnaire by students,

- project of improvement interventions.

The third case study is located in Ekaterinburg, which is one of the four biggest cities in Russia. MSW management is under development. According to the report of the Association of Environmental Universities of Russia for 2019 [27], more than 125 containers have already been installed for waste selective collection and accumulation (Table 1).

Table 1. Number of installed containers for separate waste collection at Russian universities [27].

\begin{tabular}{ccc}
\hline Name of University & Number of Containers & Notes \\
\hline $\begin{array}{c}\text { Higher School of Economics (Moscow) } \\
\text { Northern (Arctic) Federal University named } \\
\text { after M.V. Lomonosov (Arkhangelsk) }\end{array}$ & 16 & - \\
\hline $\begin{array}{c}\text { Astrakhan State Technical University } \\
\text { (Astrakhan) }\end{array}$ & 6 & 4 fractions \\
\hline $\begin{array}{c}\text { Kazan (Volga Region) Federal University } \\
\text { (Kazan) }\end{array}$ & 16 & - \\
\hline $\begin{array}{c}\text { Immanuel Kant Baltic Federal University } \\
\text { (Kaliningrad) }\end{array}$ & 4 & 3 fractions \\
\hline $\begin{array}{c}\text { Minin Nizjhy Novgorod Pedagogical Iniversity } \\
\text { (Nizjhy Novgorod) }\end{array}$ & 40 & 20 for PET bottles and \\
\hline $\begin{array}{c}\text { Altai State University (Rubtsovskii Insitute) } \\
\text { (Rubtsovsk) }\end{array}$ & 20 & 3 fractions \\
\hline $\begin{array}{c}\text { Saint Petersburg State University } \\
\text { (Saint Petersburg) }\end{array}$ & more than 600 & 12 fractions \\
\hline
\end{tabular}

Ural Federal University named after the first President of Russia B.N. Yeltsin (UrFU) is the largest federal university in Russia with more than 56,000 students and has 14 academic buildings (Figure 2).

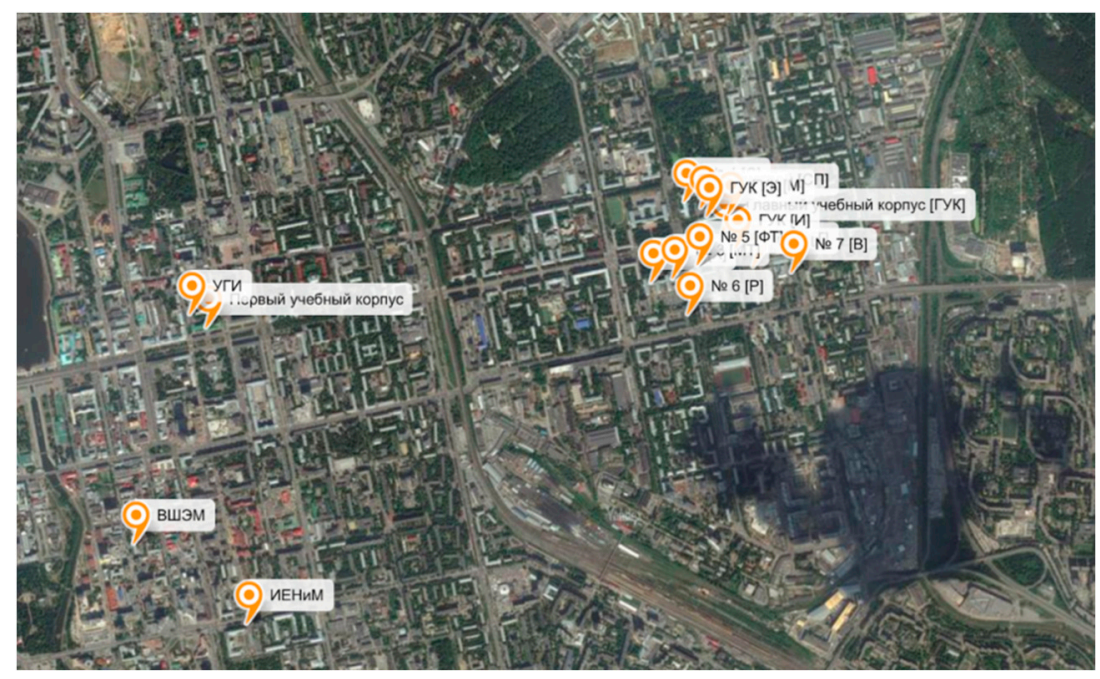

Figure 2. Area of academic buildings. 
The waste management system at UrFU does not imply separate waste collection at most academic buildings. At present, however, the UrFU Student Organization is working on a project designing an MSW selective collection system.

The methodology adopted in the present paper was based on three steps:

- analyze the strategy of MSW management in each case study, pointing out the aspect most relevant (positively and negatively) in term of sustainable management,

- propose improvements for each case study,

- discuss comparatively what emerged from the case studies.

\section{Results and Discussion}

In UniTrento, the SC is operated by means of waste bins with a volume of $120 \mathrm{~L}$. Each bin has a specific color to let the user distinguish between the different SC fractions. In addition, illustrative signs are placed on the waste bins indicating the type of waste each bin is intended to collect (Figure 3a). The waste bins placed inside the university buildings are regularly moved outside by the cleaning staff, to dedicated areas where their content is transferred into containers collecting the same waste fraction (Figure $3 b$ ). The containers are periodically emptied by the local waste management utility company. The latter is allowed to empty the containers only when their lock is left open by the cleaning staff.

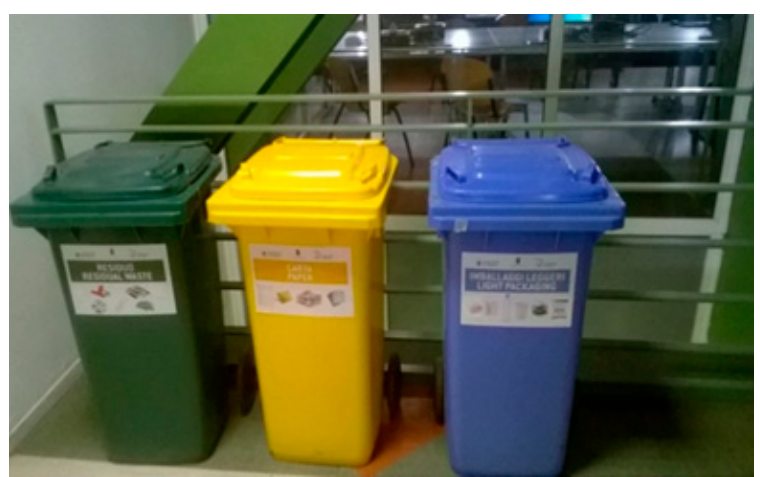

(a)

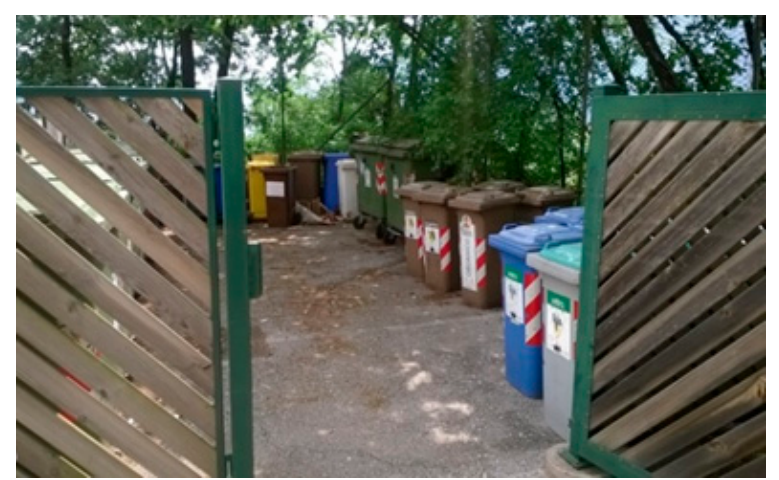

(b)

Figure 3. (a) Waste bins used in the buildings of UniTrento for selective collection (SC) and (b) external areas where the content of bins is transferred to containers.

Besides MSW and its dedicated SC system, UniTrento operates the collection of hazardous waste generated by the several laboratories present in its campuses.

Data on the RMSW production are available since 2014 and shows a decreasing trend starting from 2016 (Figure 4a). To account for the number of components of the academic community and the total surface of the buildings, additional charts contain the RMSW trend in terms of per capita (Figure $4 \mathrm{~b}$ ) and surface-specific (Figure 4c) productions. The per capita production shows a decrease in 2018, while the surface-specific production reflects the trend of the absolute RMSW production. The decrease in the generation of RMSW might be related to recent communication campaigns carried out in student residences, by improved signage on waste bins and by video-messages shared on TV screens located in halls and corridors of the buildings.

The SC of UniTrento can be further improved. In fact, the waste management system shows some critical issues that can be summarized as follows:

- In some cases, the external areas have been accessed by unauthorized users that deliver their RMSW to avoid paying the waste management tariff,

- Sometimes the external containers are left open by the cleaning staff and this allowed the utility company to empty the containers and invoice the entire volume of the containers as RMSW volume, 
- Generic waste bins are still present in many corridors and rooms, and this might induce the users to get rid of their waste without correct separation,

- Low SC performance still occurs in university buildings, and this might be related to the fact that about $11 \%$ of the students come from municipalities where the waste fractions are collected differently [28].

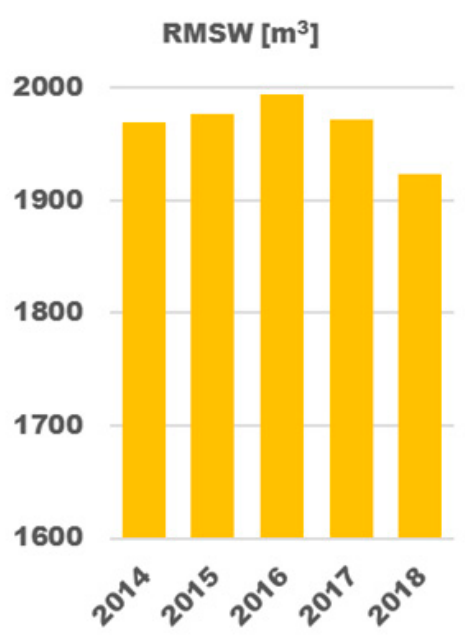

(a)

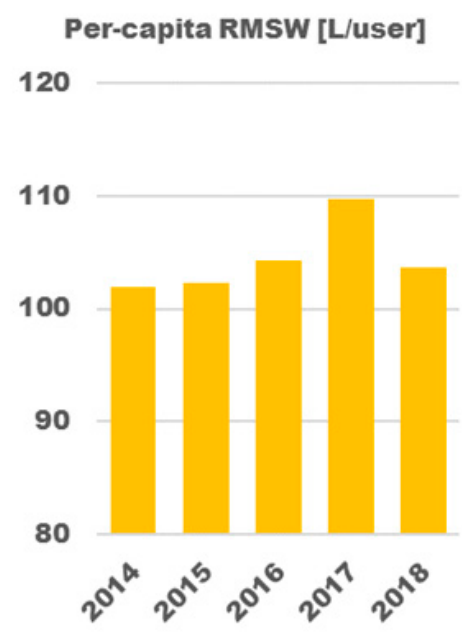

(b)

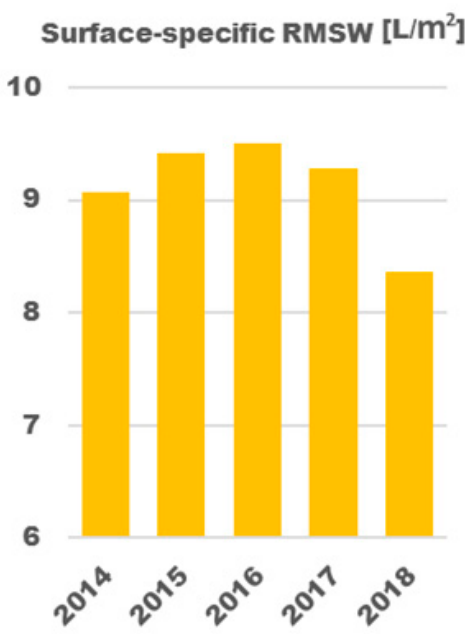

(c)

Figure 4. Trend of the production of Residual Municipal Solid Waste (RMSW) by UniTrento in (a) absolute, (b) per capita, and (c) surface-specific terms.

As a confirmation of the previous statements, Figure 5 reports a detailed analysis of the composition of the RMSW generated by UniTrento in the campuses of Trento, which was carried out by the local waste management utility company in June 2019. The company applied the "quartering method" for material analysis, in compliance with the methodology of the National Agency for Environmental Protection (ANPA) [29].

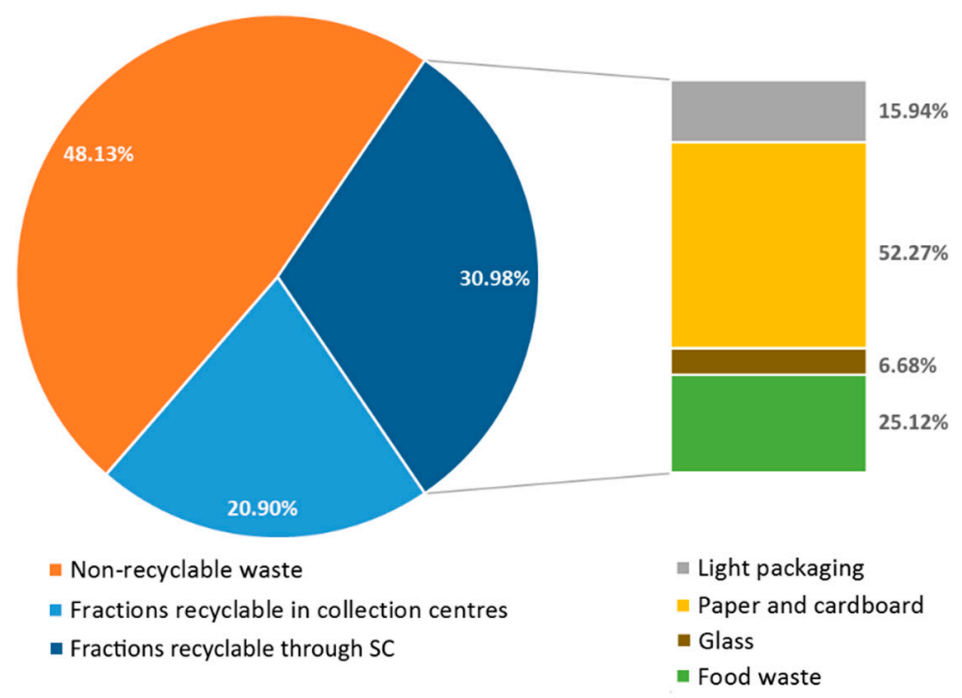

Figure 5. Composition of the RMSW collected from the campuses of Trento (values expressed as a mass percentage).

As reported in Figure 6, about half of the RMSW collected from the Trento campuses could be recycled, either through the SC or at collection centers, i.e., centers where the users can leave hazardous 
waste, bulky waste or minor fractions that can be recycled. About one-third of the RMSW is composed of waste that could be collected through the SC. Such a fraction is mainly composed of paper and cardboard, followed by food waste, light packaging, and glass.

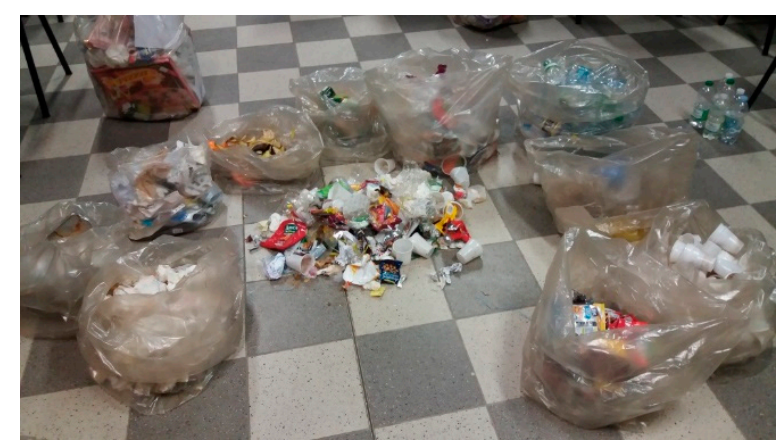

Figure 6. Example of product analysis before fraction weighting.

All the aspects previously discussed contribute to increasing the amount of the RMSW disposed of, both effectively and apparently. The also represents an additional cost for the university, which could be avoided by putting into practice simple strategies, such as:

- removing generic waste bins from the university buildings,

- $\quad$ setting up periodical communication campaigns to clearly inform the users (both students and employees) on how to correctly separate the waste fractions,

- developing a standard procedure for the correct management of waste containers in the external areas to avoid the emptying of partially filled containers by the utility company,

- implementing a surveillance strategy to monitor the external areas and avoid unauthorized users to enter.

UniTrento has recently approved its second environmental sustainability plan, which will contribute to solving the aforementioned issues. However, concerning the current year (2020), the generation of waste by UniTrento is expected to decrease significantly with respect to the previous years, due to the restriction measures undertaken to face the SARS-COV-2 emergency. Indeed, teaching activities were suspended on 5 March 2020 for precautionary reasons. Such a decision, in addition to preventing the diffusion of the new coronavirus, has drastically reduced the chances of contamination of the waste generated in the university buildings, since only urgent work activities were allowed by the dean. Consequently, the risk for operators managing the collected waste was minimized.

In Uninsubria, the MSW selective collection and management are still under an improvement process. It is clear that the fragmentation of the volumes available for university activities makes it necessary to implement additional efforts of the organization. The belonging to the RUS ${ }^{\circledR}$ gives advantages in sharing expertise and experiences.

Initial field analyses were conducted in collaboration with the cleaning staff, who, dealing with the disposal of the waste and therefore its correct separation, provided useful information on the collection methods and on the current difficulties and critical issues of the service. The product analyses were and will be carried out during the University's periods of full activity. At the moment the research is in stand-by because of the COVID-19 emergency. In Figure 6 a first look on waste composition is reported. These analyses will be conducted on the basis of the origin of the waste, i.e., from offices and classrooms for teaching, in order to evaluate the contribution of the different areas to the final production calculation of the urban waste. Representative samples will be analyzed according to the method adopted in the University of Trento (Figure 5).

The cost analyses will give the possibility to have a picture of the costs according to the current pricing methods (flat rate, or rather linked to the types of buildings and their size). The questionnaires for students are and will be distributed in order to understand their technical knowledge, perception 
regarding the MSW management at the university and their students' approach before and after the Coronavirus emergency. The results will make it possible to evaluate the student's perception regarding the issues of environmental sustainability, recycling, and circular economy. In addition, they provided useful information to have a global view of the student's perception of the efficiency of SC applied in Unisubria.

After the development of these three phases, a final project proposal to modify waste SC and management will be issued, as an improvement of the current project draft based on the partial results of the already conducted analysis. Another important aspect is related to the economic savings linked to the possible introduction of punctual pricing. In fact, if a punctual tariff were introduced, the costs would significantly increase. For example, if the tariff system used in Trentino was also implemented in the locations of Uninsubria, the current cost would increase for $>30 \%[24,25]$. The cost increase could be avoided by reaching the SC objectives achievable with the implementation of all the interventions foreseen in the project.

In UrFU, in 2018 the project of MSW selective collection system was introduced in five places at the main university building by the UrFU Student Organization (Figure 7). Sorting containers are located near canteens (2), the copy center (1), the university room (1), and the coworking area (1).

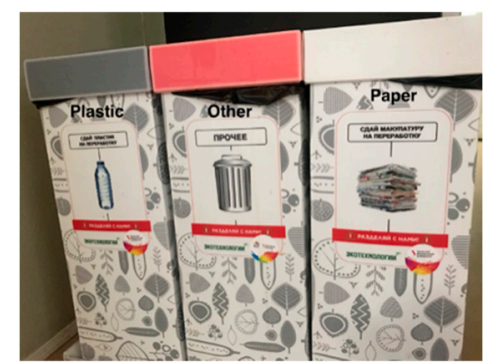

(a)

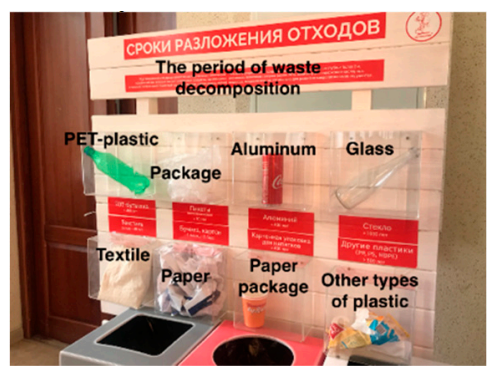

(b)

Figure 7. (a) Separate waste collection system at the main building and (b) educational stand about the period of waste decomposition of different types of waste.

In order to collect data about waste composition, authors carried out a survey among members of the UrFU Student Organization who are responsible for the project implementation. The waste from the bins contained about $40 \%$ packaging, $35 \%$ paper and cardboard, and $25 \%$ other mixed waste. In 2019 the UrFU Student Organization also set up the collection of scrap paper from March to May. In this period, $609 \mathrm{~kg}$ of scrap paper was accumulated and sold, obtaining about 1827 rubles $(25.13 €)$, including transport costs of companies.

The system analysis allowed finding the following pros and cons:

- it includes short instructions about the separate waste collection (what kind of waste should be put in baskets, etc.),

- it has two most prevalent types of waste: plastic and paper,

- waste is collected by the organization "Ecotechnology", which also provides educational courses for students,

- an insufficient volume of waste bins throughout the university buildings was found,

- an absence of organic and glass collection bins emerged.

Despite the fact that the MSW SC system has been operating for two years [30], the accurate data about waste generation is not accounted for either by the university or by subcontracting enterprises.

Based on the inventory, conducted by the authors, the main sources of waste generation at the University are the university rooms (paper, disposable dishes, folders, etc.) and vending machines (plastics). An inventory of vending machines was carried out in seven buildings of the University. The authors analyzed the product range and their characteristic designations on packaging about the categorization of containers for possible processing (e.g., plastics, chocolate, iron cans, etc.) (Table 2). 
Table 2. Designation of waste types.

\begin{tabular}{cc}
\hline Waste Type & Quantity at Vending Machines \\
\hline Polypropylene-PP & $41.1 \%$ \\
High-density Polyethylene-HDPE & $0.8 \%$ \\
Other paper (mixed paper magazines, mail)_PAP & $0.8 \%$ \\
Paper and cardboard/plastics/aluminum & $6.9 \%$ \\
Aluminum-Al & $7.3 \%$ \\
PolyethleneTerephthalate-PET & $37.3 \%$ \\
PolyvinylChloride-PVC & $0.1 \%$ \\
Plastics/Aluminum (plastic toothpaste tubes/some vacuum packed coffee bags) & $0.8 \%$ \\
HighDensityPolyethylene-HDPE & $0.7 \%$ \\
Plastic/Miscellaneous metals & $1.8 \%$ \\
Polystyrene-PS & $2.4 \%$ \\
\hline
\end{tabular}

Data on other types of waste were not recorded.

According to the collected data, the highest degree of waste accumulation is typical for products whose packaging is made of polypropylene (PP), such as chocolate, sweets, crackers and nuts, and polyethylene terephthalate (PET), such as bottles and packed sandwich.

The next step of the inventory is the analysis of waste generation in university rooms. The authors conducted a survey among employers and students about the approximate amount of waste they might generate when studying and working. The authors calculated that, from the 14 chosen university rooms (letter $\mathrm{A}$ to $\mathrm{N}$ ), each room produced annually an average of $253.57 \mathrm{~kg}$ of paper waste and a fairly large amount of plastics over 1.2 tons. About 72 bins of waste were not analyzed, being them filled with unsorted MSW (Figure 8). Employers in several university rooms prefer using plastic cups and, in some rooms, students are not allowed to bring any cups or snacks inside. In Figure 9 the emptying bins by day used for the development of the research are reported.

In spite of the project of MSW SC system implementation, waste collection in external areas of the campus are characterized by (Figure 10):

- unsuitable basket's condition,

- undifferentiated baskets,

- absence of separate waste collection,

- lack of baskets in some campus areas.

In fact, the waste management system at UrFU is in the developmental stage and the university does not have a suitable separate waste collection system. However, there are prospects for its development in the immediate future. The University supports the initiative of the UrFU Student Organization in MSW selective system development and provides necessary funding and specialists. Moreover, the government of Sverdlovsk oblast, the region in which the UrFU is located, approved the program of separate waste collection development on its territory. In the first stage, the program includes the introduction of a dual system of MSW: the waste will be divided into two main categories - food waste and non-food waste, the last category will be sent to the further processing. The UrFU is the largest university in the region, therefore it is expected that the project of MSW selective system will be introduced in all academic buildings in the near future. It is important to note that the dual system of the waste collection might be applicable in dormitories and canteens, whereas the MSW selective system designed by the UrFU Student Organization most likely might be improved and introduced at an academic building (with more than two categories of waste). At present, only five separate waste collection bins are functioning at the Main Building of UrFU (they were introduced at the end of 2018). They are used for the collection of plastics, paper, and other types of waste, but the system does not have bins for food waste and glass. The highest degree of waste accumulation is typical for products of category PP 5 (wrappers of chocolate, sweets, crackers, nuts, etc.) and PET (plastic bottles of beverages, sandwich packages). 


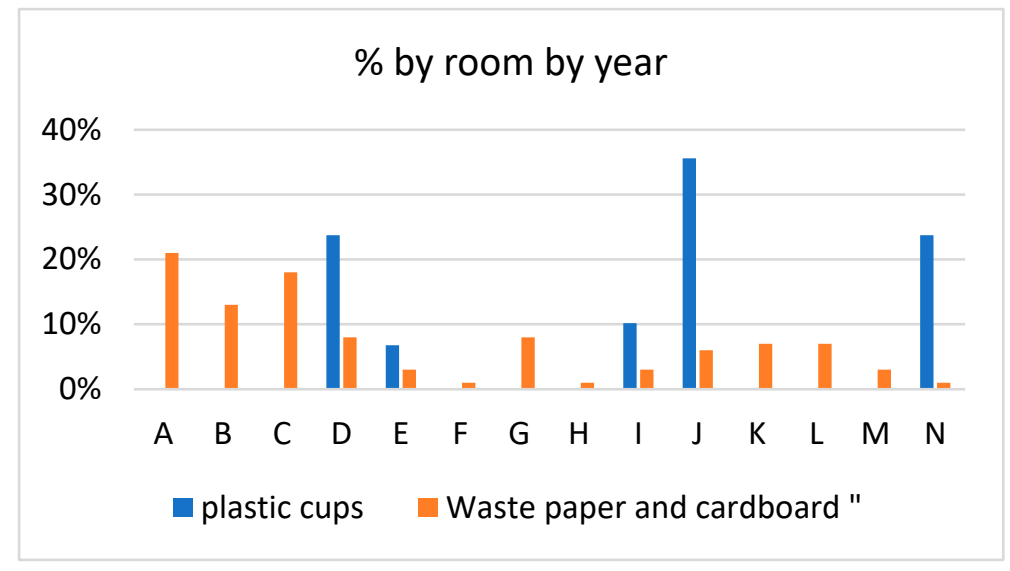

Figure 8. \% of Waste by room per year.

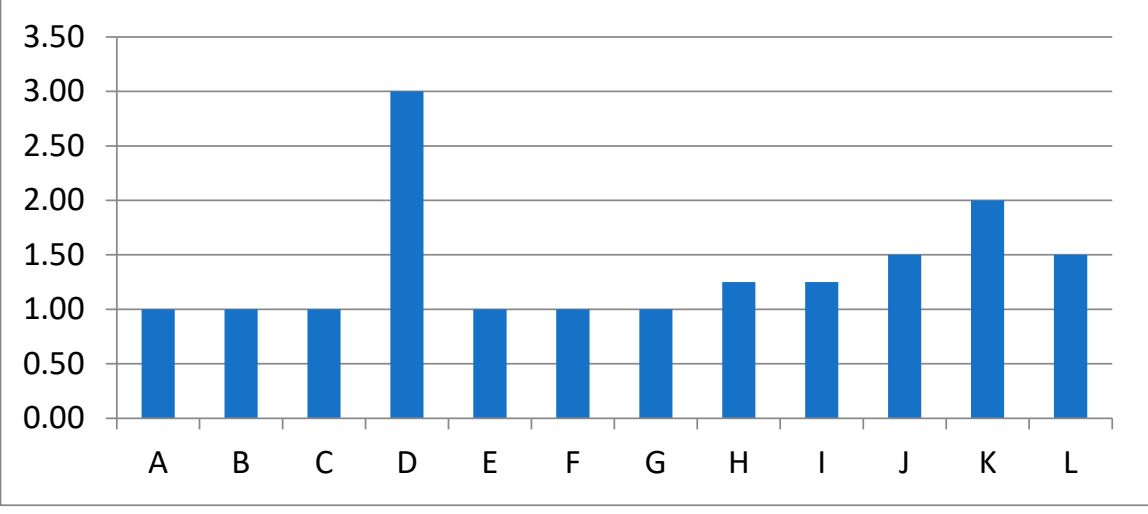

Figure 9. Average number of emptying bins (5 liters).
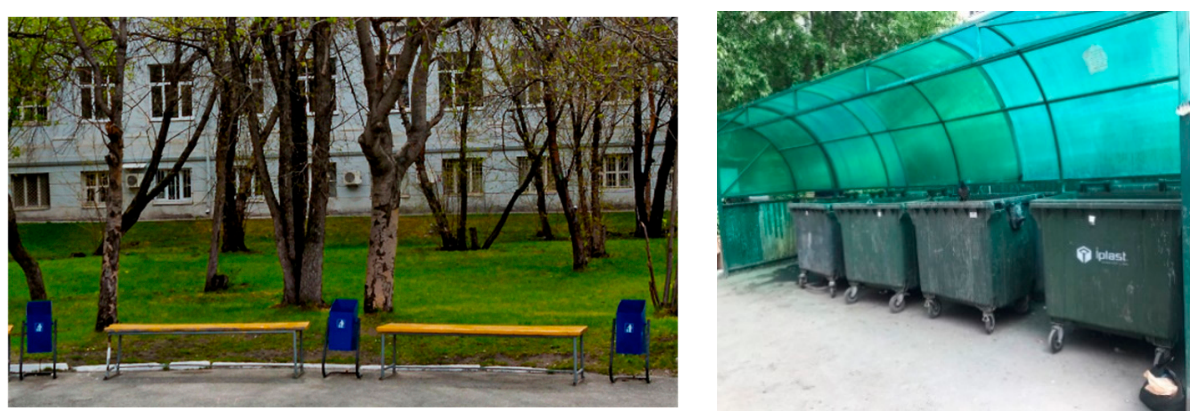

Figure 10. Bins and containers near Ural Federal University (UrFU) main buildings.

The main shortcomings of the existing waste collection system at UrFU are the following:

- There are no separate waste collection baskets at dormitories and other buildings,

- University and organizations do not provide accurate data about overall waste collection, especially about the separate waste collection,

- In some campus territories, there is a lack of undifferentiated baskets causing problems with overall waste collections.

- Three waste management systems discussed above, have several drawbacks that should be taken into account. UniTrento demonstrated the most efficient waste management system whereas UrFU showed the initial stage of the SC implementation. The summarized data and advisable improvements in the waste management system at universities are provided in Table 3. 
Table 3. The current design and possible trends for further waste management systems development in the Universities.

\begin{tabular}{|c|c|c|}
\hline University & The Present Waste Management System & Proposed Improvements \\
\hline University of Trento, Italy & $\begin{array}{l}\text { The SC is implemented in every university building; } \\
\text { the SC is designed to collect paper and cardboard, light packaging, } \\
\text { residual fraction, nearby canteens the SC also includes glass and food } \\
\text { waste, and the last fraction is also available near vending machines; } \\
\text { The university carries out communication campaigns about the } \\
\text { necessity and importance of separate waste collection; } \\
\text { The university has an efficient waste management system; } \\
\text { The significant amount of generic waste bins causes problems with } \\
\text { correct waste separation; } \\
\text { Students who come from other municipalities might have difficulties } \\
\text { with the SC; } \\
\text { Unauthorized users might avoid paying the waste management tariff }\end{array}$ & $\begin{array}{l}\text { Generic waste bins should be removed from the } \\
\text { university buildings; } \\
\text { Communication campaigns should be set up periodically; } \\
\text { A standard procedure for the correct management of waste } \\
\text { containers in the external areas should be developed to } \\
\text { reduce costs; } \\
\text { A monitoring system should be implemented in order to avoid } \\
\text { unauthorized users to enter }\end{array}$ \\
\hline Insubria University, Italy & $\begin{array}{l}\text { The SC is not totally implemented at university buildings; } \\
\text { The university participates to the RUS }{ }^{\circledR} \text { WW group; } \\
\text { The per capita cost of managing urban waste at the regional level is } \\
\text { lower than the national average ( } 126 \text { euros in comparison to } \\
174 \text { euros) }\end{array}$ & $\begin{array}{l}\text { Generic waste bins should be removed from the university } \\
\text { buildings; } \\
\text { Communication campaigns should be set up periodically; } \\
\text { A standard procedure for the correct management of waste } \\
\text { containers in the external areas should be developed to } \\
\text { reduce costs; } \\
\text { Introduction of punctual pricing }\end{array}$ \\
\hline Ural Federal University, Russia & $\begin{array}{l}\text { The university does not have a well-organized waste management } \\
\text { system at the moment; } \\
\text { The SC project started in } 2018 \text { and currently, there are only five } \\
\text { places with separate waste collection bins which are located only at } \\
\text { the main university buildings; } \\
\text { The current SC includes only three fractions: plastics, paper, and } \\
\text { other waste; } \\
\text { The SC project includes special instructions about SC and } \\
\text { its importance; } \\
\text { Insufficient volume of basket types throughout the university; } \\
\text { The absence of separate waste collection and the lack of baskets in } \\
\text { some external areas; } \\
\text { Annually the university announces the collection of scrap paper }\end{array}$ & $\begin{array}{l}\text { The SC should be implemented in all buildings and especially } \\
\text { in dormitories; } \\
\text { The following fractions should be implemented: residual } \\
\text { fractions, glass, and food waste; } \\
\text { The data about the waste collection should be collected and } \\
\text { analyzed periodically }\end{array}$ \\
\hline
\end{tabular}


The proposals for improvements listed in Table 3 could be implemented with the creation of a sustainability office directing the most operational structures of a university (e.g., purchasing and building-stock departments). Table 3 lists a group of good practices tailored for the specific universities studied in this paper, but the list could be enlarged to include possible initiatives that depend on the situation of other universities and on their margins for improvements. The implementation of a waste management system in a university should start from a detailed analysis of the weaknesses of the current system and of the improvements achievable. A recognition of the best practices adopted by other universities (e.g., awareness-raising campaigns, clear instructions on SC, clear and detailed procedures for the movement and collection of waste bins and close collaboration with waste management companies) should follow this first step and could be facilitated by the mutual exchange of information allowed by university networks. It is worth considering that, if a punctual tariff were used by universities in general, interventions aiming at increasing the SC rate would generate economic savings too, which could be invested in additional sustainability initiatives. These lets consider the punctual tariff as a good practice to reduce the amount of RMSW.

\section{Conclusions}

MSW management in universities is a topic growing in interest in the sector. The present paper enlarged the database of universities committing to increase their level of sustainability, with a specific focus on the waste sector. The analyzed case studies demonstrate that optimizing SC is a complex subject involving the whole university community as the MSW generation concerns a wide variety of areas (rooms, offices, etc.). The kind of fractions that characterize the MSW generated in universities are suitable for high SC efficiencies. In order to obtain that, a potential pathway is the adoption of a tariff based on the amount of residual MSW delivered to the collection company. The present paper confirms what emerged from the recent literature (still scarce): the dissemination of source separation criteria within the community and the sharing of good practices between universities play a key role in improving the level of sustainability in the education sector. However, possible ameliorative interventions must consider local policies in terms of waste management. Indeed, if a well-established waste management system aiming at increasing the recycling rate of waste is not implemented in the area of a university, this will inevitably limit the number of good practices a university could set up. The represents a limitation, which might not depend on the universities themselves, but which may indirectly reduce the margins for improvements.

The present paper can be considered as the first step for MSW management implementation and improvement at the university level. The research did not have the ability to continue because of the COVID-19 situation (all the structures being closed). However, the authors intend to proceed with new research in order to have more data and to be able to compare them with the ones before the emergency. Finally, the obtained results will be used to re-calibrate the strategies of a selective collection in each university.

Author Contributions: Conceptualization: E.C.R.; methodology: E.C.R., M.S. and A.K.; validation: E.C.R., E.R.M. and V.T.; investigation: A.K., M.C. and M.S.; writing-review and editing: E.C.R., A.K. and M.S.; visualization: V.T.; supervision: E.C.R., E.R.M. and V.T.; All authors have read and agreed to the published version of the manuscript.

Funding: This research received no external funding.

Acknowledgments: The authors wish to thank Dolomiti Energia Spa and, especially, C. Realis and G. Baldessarri Antoniolli for the data on the fractions contained in the residual waste produced by UniTrento. The research was supported by Act 211 Government of the Russian Federation, contract № 02.A03.21.0006.

Conflicts of Interest: The authors declare no conflict of interest.

\section{References}

1. Zulkifli, A.A.; Yusoff, M.Z.M.; Manaf, L.A.; Zakaria, M.R.; Roslan, A.M.; Ariffin, H.; Shirai, Y.; Hassan, M.A. Assessment of municipal solid waste generation in Universiti Putra Malaysia and its potential for green energy production. Sustainability 2019, 11, 3909. [CrossRef] 
2. Ramamoorthy, R.; Poyyamoli, G.; Kumar, S. Assessment of solid waste generation and management in selected school campuses in Puducherry region, India. Environ. Eng. Manag. J. 2019, 18, 499-512.

3. Jayaprakash, J.; Jagadeesan, H. Sustainable Waste Management in Higher Education Institutions-A Case Study in AC Tech. In Green Engineering for Campus Sustainability; Anna University: Chennai, India, 2019; pp. 163-172.

4. Rodzi, R.M.; Nopiah, Z.M.; Basri, N.E.A. Analysis of solid waste generation and composition in Malaysia TVET campus. Int. J. Integr. Eng. 2019, 11, 158-170.

5. Yusoff, S. Toward integrated and sustainable waste management system in University of Malaya: UM zero waste campaign. E3S Web Conf. 2018, 48, 04007. [CrossRef]

6. Rada, E.C.; Bresciani, C.; Girelli, E.; Ragazzi, M.; Schiavon, M.; Torretta, V. Analysis and measures to improve waste management in schools. Sustainability 2016, 8, 840. [CrossRef]

7. Adeniran, A.E.; Nubi, A.T.; Adelopo, A.O. Solid waste generation and characterization in the University of Lagos for a sustainable waste management. Waste Manag. 2017, 67, 3-10. [CrossRef] [PubMed]

8. Tiew, K.G.; Kruppa, S.; Basri, N.E.A.; Basri, H. Municipal solid waste composition study at Universiti Kebangsaan Malaysia campus. Aust. J. Basic Appl. Sci. 2010, 4, 6380-6389.

9. Liao, C.; Li, H. Environmental education, knowledge, and high school students' intention toward separation of solid waste on campus. Int. J. Environ. Res. Pub. Health 2019, 16, 1659. [CrossRef] [PubMed]

10. De Feo, G.; Ferrara, C.; Iannone, V.; Parente, P. Improving the efficacy of municipal solid waste collection with a communicative approach based on easily understandable indicators. Sci. Tot. Environ. 2019, 651, 2380-2390. [CrossRef] [PubMed]

11. Grodzińska-Jurczak, M. The relation between education, knowledge and action for better waste management in Poland. Waste Manag. Res. 2003, 21, 2-18. [CrossRef] [PubMed]

12. Rada, E.C.; Cioca, L.I. Optimizing the Methodology of Characterization of Municipal Solid Waste in EU under a Circular Economy Perspective. Energy Procedia 2017, 119, 72-85. [CrossRef]

13. Sustainable Development Goals. Available online: https://sustainabledevelopment.un.org/?menu=1300 (accessed on 14 May 2020).

14. Perotto, E.; Prandstraller, A. Sustainable waste management at Universities. In Proceedings of the 17th International Waste Management and Landfill Symposium, Forte Village, Cagliari, Italy, 30 September-4 October 2019.

15. RUS ${ }^{\circledR}$. Available online: https://sites.google.com/unive.it/rus/home (accessed on 1 April 2020).

16. Malinauskaite, J.; Jouhara, H.; Czajczyńska, D.; Stancev, P.; Katsou, E.; Rostkowski, P.; Thorne, R.J.; Colon, J.; Ponsa, S.; Al-Mansour, F.; et al. Municipal solid waste management and waste-to-energy in the context of a circular economy and energy recycling in Europe. Energy 2017, 141, 2013-2044. [CrossRef]

17. Plastinina, I.; Teslyuk, I.; Dukmasova, N.; Pikalova, E. Implementation of circular economy principles in regional solid municipal waste management: The case of Sverdlovskaya Oblast (Russian Federation). Resources 2019, 2, 90. [CrossRef]

18. Rumyantseva, A.; Berezyuk, M.; Savchenko, N.; Rumyantseva, E. Modern Technologies of Processing Municipal Solid Waste: Investing in the Future. IOP Conference Series: Earth and Environmental Science; IOP Publishing: Bristol, UK, 2012; Volume 72, p. 012015.

19. Fomin, E.P.; Alekseev, A.A.; Fomina, N.E.; Dorozhkin, V.E. The scenario approach to the development of regional waste management systems (Implementation experience in the regions of Russia). Int. J. Environ. Sci. Educ. 2016, 11, 7551-7562.

20. Rapporto Rifiuti Urbani (Urban Waste Report)_Edizione 2019. Available online: http: //www.isprambiente.gov.it/files2019/pubblicazioni/rapporti/Rapporto\%20Rifiuti\%20Urbani_Dati\% 20di\%20Sintesi_n\%20314_2019_DEF.pdf (accessed on 1 April 2020).

21. Rada, E.C.; Zatelli, C.; Mattolin, P. Municipal solid waste selective collection and tourism. WIT Trans. Ecol. Environ. 2014, 180, 187-197.

22. Ragazzi, M.; Fedrizzi, S.; Rada, E.C.; Ionescu, G.; Ciudin, R.; Cioca, L.I. Experiencing Urban Mining in an Italian Municipality towards a Circular Economy vision. Energy Procedia 2017, 119, 192-200. [CrossRef]

23. Schiavon, M.; Ragazzi, M.; Coller, G.; Ferronato, N.; Torretta, V.; Rada, E.C. A methodology to support decisions towards economic and environmental sustainability in public contexts: Application to hand-drying options. WIT Trans. Ecol. Environ. 2019, 222, 59-71. 
24. Rada, E.C.; Zatelli, C.; Cioca, L.I.; Torretta, V. Selective collection quality index for municipal solid waste management. Sustainability 2018, 10, 257. [CrossRef]

25. Di Di Foggia, G.; Beccarello, M. The impact of a gain-sharing cost-reflective tariff on waste management cost under incentive regulation: The Italian case. J. Environ. Manag. 2020, 265, 110526. [CrossRef] [PubMed]

26. Ferronato, N.; Dalla Valle, L.; Torretta, V. Valutazione della gestione dei rifiuti urbani in un campus universitario italiano: Verso una migliore raccolta differenziata (Assessment of municipal waste management on an Italian university campus: To a better selective collection). Ingegneria Dell'ambiente 2018, 5, 333-346.

27. Association of Green Universities in Russian Federation. Available online: http://xn--b1afaaheyr0d3de.xn-p1ai/ (accessed on 1 April 2020).

28. Ragazzi, M.; Rada, E.C.; Abbà, A.; Schiavon, M. Parameters analysis for a sustainable management of solid waste in university buildings. In MATEC Web of Conferences, Proceedings of the 2019 8th International Conference on Transportation and Traffic Engineering (ICTTE 2019), Auckland, New Zealand, 19-21 December 2019; EDP Sciences: Les Ulis, France, 2020; Volume 305, p. 00054.

29. ANPA. Analisi Merceologica dei Rifiuti Urbani; Technical Report RTI CTN_RIF 1/2000; Agenzia Nazionale per la Protezione dell'Ambiente: Rome, Italy, 2000.

30. Official Website of UrFU Student Organization. Available online: https://posurfu.ru/ (accessed on 14 May 2020).

(C) 2020 by the authors. Licensee MDPI, Basel, Switzerland. This article is an open access article distributed under the terms and conditions of the Creative Commons Attribution (CC BY) license (http://creativecommons.org/licenses/by/4.0/). 